Article

\title{
Strategy and Steering in Governance: The Changing Fates of the Argentine Planning Council
}

\author{
Rodrigo Alves Rolo ${ }^{1}$, Kristof Van Assche ${ }^{2}$ and Martijn Duineveld ${ }^{3, *}$ \\ ${ }^{1}$ National Institute of Agricultural Technology, Argentina; E-Mail: alvesrolo.rodrigo@inta.gob.ar \\ 2 Department of Earth and Atmospheric Sciences, University of Alberta, Canada; E-Mail: vanassch@ualberta.ca \\ ${ }^{3}$ Department of Environmental Sciences, Wageningen University, The Netherlands; E-Mail: martijn.duineveld@wur.nl \\ * Corresponding author
}

Submitted: 29 January 2021 | Accepted: 1 April 2021 | Published: 25 June 2021

\begin{abstract}
Based on a detailed study of the return of national-level planning in Argentina as embodied by COFEPLAN, the national planning council, we develop a conceptual framework to analyse the possibilities and limits of steering in governance. We lean on the theoretical apparatus of evolutionary governance theory and use the concepts of goal dependency, interdependency, path dependency and material dependency (effects in governance) to analyse the reality effects of strategy (effects of governance). Methodologically, our study relies on archival work and semi-structured interviews with planning scholars and public officials from different levels of government. We show that, although material and discursive reality effects were abundant in the evolution of Argentine planning policies, dependencies and discontinuities undermined both the central steering ambitions of the government and the innovative potential of the new planning schemes. The dramatic history of the Argentine planning system allows us to grasp the nature of dependencies in a new way. Shocks in general undermine long-term perspectives and higher-level planning, but they can also create windows of opportunity. The internal complexity and the persistence of Peronist ideology in Argentina can account for the revivals of national-level planning in very different ideological contexts, but the recurring shocks, the stubborn difference between rhetoric and reality, the reliance on informality, created a landscape of fragmented governance and often weak institutional capacity. In that landscape, steering through national-level planning becomes a tall order.
\end{abstract}

\section{Keywords}

Argentina; COFEPLAN; goal dependency; governance; performativity; policy implementation; reality effects; strategic planning

\section{Issue}

This article is part of the issue "Steering in Governance: Evolutionary Perspectives" edited by Kristof Van Assche (University of Alberta, Canada / University of Bonn, Germany) and Raoul Beunen (Open University, The Netherlands).

(C) 2021 by the authors; licensee Cogitatio (Lisbon, Portugal). This article is licensed under a Creative Commons Attribution 4.0 International License (CC BY).

\section{Introduction}

Planning in Argentina has undergone many transformations in its roughly 75 years of existence. Changing powers, shifting ideologies and fluctuating stakeholder configurations redefined what planning is and what it could do (Müller \& Gómez, 2013; Settimi \& Audino, 2008). As such, Argentina is a good place to study the potential and limits of planning as steering, especially since national-level planning was attempted several times. And it came back in recent years. In the more recent manifestations of national-level planning, the Federal Council for Planning and Territorial Ordering (COFEPLAN) is one of the most significant organisations. We study how this organisation evolved, as it sheds a light on the changing fates of national-level planning, and, with that, central steering ambitions in Argentina. One can thus speak of a nested case study, with COFEPLAN enabling 
us to grasp the difficulties of (re)introducing national planning, and national planning shedding a light on planning-as-steering.

Theoretically, our work is framed by evolutionary governance theory (EGT; Beunen et al., 2015; Van Assche et al., 2014). EGT offers a unique perspective on the non-linearity of transformation in governance by giving central place to processes of co-evolution and the dependencies which develop. It offers a distinct picture of continuity and discontinuity in governance and, at the same time, an explanation of limits and possibilities for steering. We combine the EGT-derived concepts with a version of strategy thinking which owes to the strategy-as-practice perspective (Jarzabkowski, 2005; Whittington, 1996) and critical management studies (Adler et al., 2007; Alvesson \& Willmott, 2011). As steering in governance can be understood as strategic in nature, strategy thinking enters the picture quite naturally.

Methodologically, our study relies on archival records regarding the evolution of COFEPLAN and, more broadly, the history of national-level planning in Argentina. Consultancy reports, minutes of Council meetings, national plans for economic development, and other documents complemented these sources. We also conducted 23 semi-structured interviews with national and international planning scholars and public officials from different levels of government.

The next section introduces key concepts from EGT which will feature in the case analysis, as well as our strategy concept and its sources. We then present a brief historical account of national-level planning policies in Argentina. After which we position COFEPLAN in the Argentine system of planning and governance. A retrospective gaze at the making of COFEPLAN becomes a vantage point from which to rethink recurrent steering ambitions within a shifting governance environment. We analyse the functioning of COFEPLAN in a governance environment scarred by a series of economic and political shocks, yet also by remarkable continuities. Finally, we consider implications for the broader topic of (central) steering in governance.

\section{Theoretical Framing}

\subsection{Evolutionary Governance Theory}

EGT understands governance as radically evolutionary. That is, all constituent elements of governance configurations transform each other over time in a process of co-evolution. This means that a governance path is never entirely predictable, while each step in its evolution is constrained by the previous state of the system. Path dependency is thus a central concept, one that is not new. It has been analysed in institutional economics (David, 1994; Dopfer, 1991; North, 1990, 2005), political science (Greener, 2005; Pierson, 2000), economic geography (Boschma \& Martin, 2007; Martin \& Sunley, 2006), public policy (Liebowitz \& Margolis, 1995; Torfing, 2009) and other disciplines. What gives EGT its distinct theoretical flavour is that present and future similarly affect the reproduction and thus evolution of a governance system.

For the present, this is understood through the idea of interdependencies, between actors, between institutions (policies, plans, laws), between actors and institutions. And it is understood as an effect of powerknowledge configurations. Understandings of reality embedded in the governance configuration, either through identification (in the case of actors), or through codification (ideas coded into the rule system of institutions) shape and constrain the continuing game of interactions within governance. This idea of interdependence affecting the evolution of governance stems from systems theory (Luhmann, 1995; Teubner, 1993, 2011) and institutional economics (Greif, 2006; Seabright, 2010).

To grasp the influence of the future, EGT coined the concept of goal dependencies. Goal dependencies are the effects of images, narratives or visions of the future on the reproduction of governance in the present (cf. Beckert, 2016). The images of the future produced in the system affect the current functioning of the system. This can be towards 'implementation,' but also in very different and indirect manners. Such insight is compatible with both systems theory (e.g., Luhmann, 1990, 2008) and post-structuralism, especially in the Foucauldian tradition. Both utopia and heterotopia, and every dream in between, can affect the thought and action of actors, the use and interpretation of institutions and the production of new ones (Foucault \& Miskowiec, 1986).

A fourth dependency which has been recognized more recently (Birchall, 2020; Schlüter et al., 2020), partly under influence of recent developments in geography, is that of material dependencies. The most recent version of transition studies (e.g., Fuenfschilling \& Truffer, 2016; Hoffman, 2013) similarly came to recognize the importance of materiality for the shaping of transition pathways. Material dependencies are the effect of material objects and environments on the functioning of governance. These effects can be recognized and acted upon in governance, but not necessarily so-as routinely recognized in the environmental policy and climate change literatures (Beunen \& Lata, 2021).

Of particular importance, to grasp the unicity and explanatory power of EGT, is the idea that governance evolution never stops, whatever key decisions are taken or whatever momentous event takes place. Because of its radically co-evolutionary character, EGT sees-here in parallel with actor-network theory (Latour, 2005)potential transformations (and conservatisms) coming from many directions. So, an idea can shape an actor who clashes with other actors over the creation of a new institution but comes to understand that a reinterpretation of an existing institution, a new narrative publicly framing this reinterpretation can create a discourse coalition (cf. Hajer, 1993). And she comes to understand that this coalition can further the initial goal 
by transforming it into a more public goal. The configuration of co-evolving actors and institutions, of power and knowledge, keeps itself in motion through this diversity in pathways and connections. EGT, which was developed not in opposition to classic public policy literature on continuity and change in governance (e.g., Streeck \& Thelen, 2005) but emerged from a distinct set of sources (institutional economics, post-structuralism, social systems theory), thus comes to a distinct understanding of continuity and change.

Certainly, future work can explore a partial integration, especially as some of the sources of EGT have also found an audience within public policy (especially institutionalism, and, to a lesser degree, post-structuralism) and as some of the key authors in mainstream public policy come to similar insights on certain points-especially on path dependencies (Schreyögg \& Sydow, 2009) and, to a lesser extent, on power (Flyvbjerg, 1998; Richardson, 1996; Seabrooke \& Wigan, 2016). We wholeheartedly embrace such aspirations, but for our present purposes, it suffices to point out that EGT offers a distinct and cohesive perspective on change in governance, and on deliberate and strategic attempts at transforming governance. EGT speaks of rigidity and flexibility in governance evolution, with dependencies helping to explain rigidity, and flexibility coming from deliberate path creation but also from the interplay between the dependencies. In keeping with systems theory and complexity theory (Byrne, 1998; Thrift, 1999), the pattern of feedback loops which can emerge from such interplay creates its own unanticipated effects, and these can be exploited by actors to shift the path of governance.

\subsection{Strategy, Goal Dependencies and Reality Effects}

Goal dependencies become especially relevant when shared visions for the future are articulated discursively and become explicitly or implicitly encoded in policies, plans, project or laws. Such encoding more likely affects the power/knowledge nexus and the actor/institutions configuration (Djanibekov et al., 2018; Van Assche et al., 2014). Furthering goals cannot fully avert nor abruptly suspend the 'stickiness' created by path dependencies and the interdependent web of actors and institutions in the governance regime.

Goal dependencies become central to the understanding of a particular governance path when strategies emerged in that path, aiming for societal steering. This insight requires us to introduce two more concepts into our conceptual frame: strategy itself, and secondly, reality effects. Strategy has been studied primarily within the confines of private organisations, within management studies. There is a tradition of strategic (long-term) spatial planning (e.g., Albrechts, 2004), and an emerging tradition of strategic management in public organisations (e.g., George, 2020). Both provide valuable insights in governance for the long term and in the necessity for public actors to think strategically. Yet, few have con- sidered the possibilities and limits of strategy at community level, strategy in and through governance, and thereby taken on board recent insights in both strategy and governance.

We argue that the ideas on strategy espoused in the so-called strategy-as-practice literature (Jarzabkowski et al., 2007; Johnson et al., 2007), and the strategy literature inspired by social systems theory can be utterly useful here. For the strategy-as-practice thinkers, and for Mintzberg $(1978,1987)$, one of their key sources of inspiration, strategies emerge as a result of ongoing bricolage of intention and unanticipated effects. For the systemsinspired thinkers (some of them also versed in strategyas-practice theory, as e.g., Seidl, 2007) strategies are constantly reinterpreted, as organisations evolve, as situations can be reinterpreted as success or failure, and results can be reinterpreted as resulting from strategy or not. Furthermore, and this also resonates with the critical management literature (Grey \& Willmott, 2005), strategy concepts are also evolving, with new strategy concepts continuously emerging and affecting the functioning of organisations and administrations (Fairhurst \& Putnam, 2004).

Strategy at community level has to pass through governance. If we adopt the EGT understanding of governance, it transpires quickly that a functioning strategy has to be both an institution linking other institutions and a narrative on the future (cf. Wittmayer et al., 2019). The production and effects of strategy are shaped by the pattern of flexibility and rigidity as diagnosed by EGT. Rather than speaking of implementation vs. non implementation, we can speak then of goal dependencies triggered by strategies (see before). While the goal dependencies concept focuses on the system of governance itself (effects of futures on current governance), the concept of 'reality effects,' draws our attention to the effect outside the sphere of governance, e.g., in the environment, the community for which the strategy is destined. Reality effects are those effects of the strategy which alter discursive realities or materiality, insofar as noticed. Here, 'noticed' means taken up in discourse. Material effects, on the one hand, refer to changes in the physical environment that "matter in governance as reality effects only after they are observed and interpreted, and hence only if their meaning is constructed in social systems" (Van Assche et al., 2020, p. 700). Discursive effects, on the other hand, refer to "hanging ways of understanding stemming from the strategy" (Van Assche et al., 2020, p. 700). Policies, plans and projects can create reality effects and trigger goal dependencies, yet only on rare occasions they bring the envisioned reality into being exactly as it had been imagined.

In the next sections, we deploy this conceptual frame to analyse the evolution of COFEPLAN in the context of an Argentine governance system marked by both shocks and strong continuities (see Alves Rolo, 2021). The existence of COFEPLAN itself is taken as a sign of re-emerging steering ambitions. 


\section{Planning in the Governance of Argentina}

\subsection{A Brief Review of Argentine Planning}

In order to understand the role of planning in the governance system of Argentina, we need to mention first the history of dramatic shocks in the 20th century. Economic crises, military coups and changes in ideologies made the development of a stable planning system virtually impossible. The maintenance of long-term perspectives as such was hard at times. Nevertheless, Argentina did embrace rather ambitious planning schemes, and something of a national planning tradition developed. We refer to Figure 1 for an overview of these discontinuities in governance, with implications for discontinuities in planning.

National-level planning in Argentina can be traced back to the beginning of the 20th Century (Elena, 2005). Larger cities were the primary target of planning interventions, as they were expected to drive economic development. The choice can be explained by the rapid urbanization of Argentina, as well as the sheer size of the country (Cerrutti \& Bertoncello, 2006). Guided urban redevelopment and expansion were strategies for addressing social problems, by providing housing for the poor (Crot, 2006), and giving them a fresh start in a new environment. Most of the funding, however, went to infrastructure. Infrastructure investment aimed at spurring economic development in the main urban nodes and was intended to visibly legitimize the narrative of national development (Ciccolella, 2006). Despite the initial rhetoric of more comprehensive planning, over time planning became seen as infrastructure development, and planners and non-state actors (e.g., architects, urbanists, engineers) learned that plans were more likely to have an impact if presented as 'public works' (Rigotti, 2014).

After the Second World War, the central government became more ambitious. National-level planning was still seen as promoting economic development through infrastructure projects, but those projects were now spread throughout the country. Meanwhile, resource extraction and urban development in more remote areas were encouraged (Gómez \& Lesta, 2008). The National Planning Council, created in 1951 as part of the Peronist state apparatus, was responsible for the elaboration of the Second Five-Year Plan (1952-1955) that would define the orientation of Perón's second term (Official Bulletin of the Argentine Republic, 1951). However, the Council was dissolved after the coup of 1955 (Undersecretariat of Territorial Planning of Public Investment, 2015). Emerging state-backed monopolies (builders, developers) and networks (landowners, industrialists) were not backing the planning council, while the political opposition and key stakeholders were absent and recurring economic crises reduced the scope of state planning.

By the 1960s, the negative effects of rapid urbanisation were becoming clear and the push towards devel- opment across the regions was intensified. In this context, a renewed emphasis on planning was endorsed by the Alliance for Progress, a development aid organization promoted by the Kennedy administration in 1961. The agreement provided funding to encourage spatial planning and proposed a set of economic, political and social measures. Redistribution of wealth and improving the living standards of the working classes were the main goals. This impulse resulted in the creation of the National Development Council (CONADE) and the National Planning System in 1961.

CONADE was theoretically informed by ECLAC, a regional commission of the UN that accompanied the reforms proposed by the Alliance for Progress and focused on development of peripheral regions. CONADE intervened in a multiplicity of policy domains: agriculture, industry, transport, housing, health, energy, etc. One of the main CONADE initiatives was the National Development Plan (1965-1969), during the administration of President Arturo Illia (1963-1966). Its implementation, however, was interrupted by the military coup by General Juan Carlos Onganía (1966), who did not dissolve CONADE but reoriented its work towards security policies.

In 1970 the toppling of Onganía by General Roberto Levingston (1970-1971) spurred the implementation of a National Development Plan in an attempt to improve the dynamism of the internal market. Against the background of a messy urbanisation process driven by massive rural-urban migration, the plan proposed the creation of development poles. The state would support relocation of industries to peripheral regions. Although the plan as a whole did not succeed, development poles did appear, particularly in Patagonia (Álvarez, 2016).

Perón's return as President in 1973 gave a new impulse to planning through the Triennial Plan for Reconstruction and National Liberation (1974-1977). This plan sought to mobilize economic policy towards social justice, 'rebuilding' the state, economic independence and Latin American integration. It came with a political strategy for implementation that included agreements with various political parties, unions, governors, and others. Public forums hosted by unions, were organized in factories and at universities to discuss the plan. However, the economic situation after the international oil crisis (1973) and clashes between the right and left wings of the Peronist movement after Perón's death in 1974 , among other factors, made this agreement untenable. In this convoluted political and economic situation, on March 24, 1976 Argentina suffered its sixth coup.

The crisis of the welfare state and the incipient rise of neo-liberalism as a new order in the mid-1970s were accompanied by a process of de-legitimization of the steering state. The concept of a small, efficient, and enabling state gained traction (Marengo, 2008). This resulted in a profound reform of the political and institutional structure of the country. Historically national competences were decentralized. The new development 

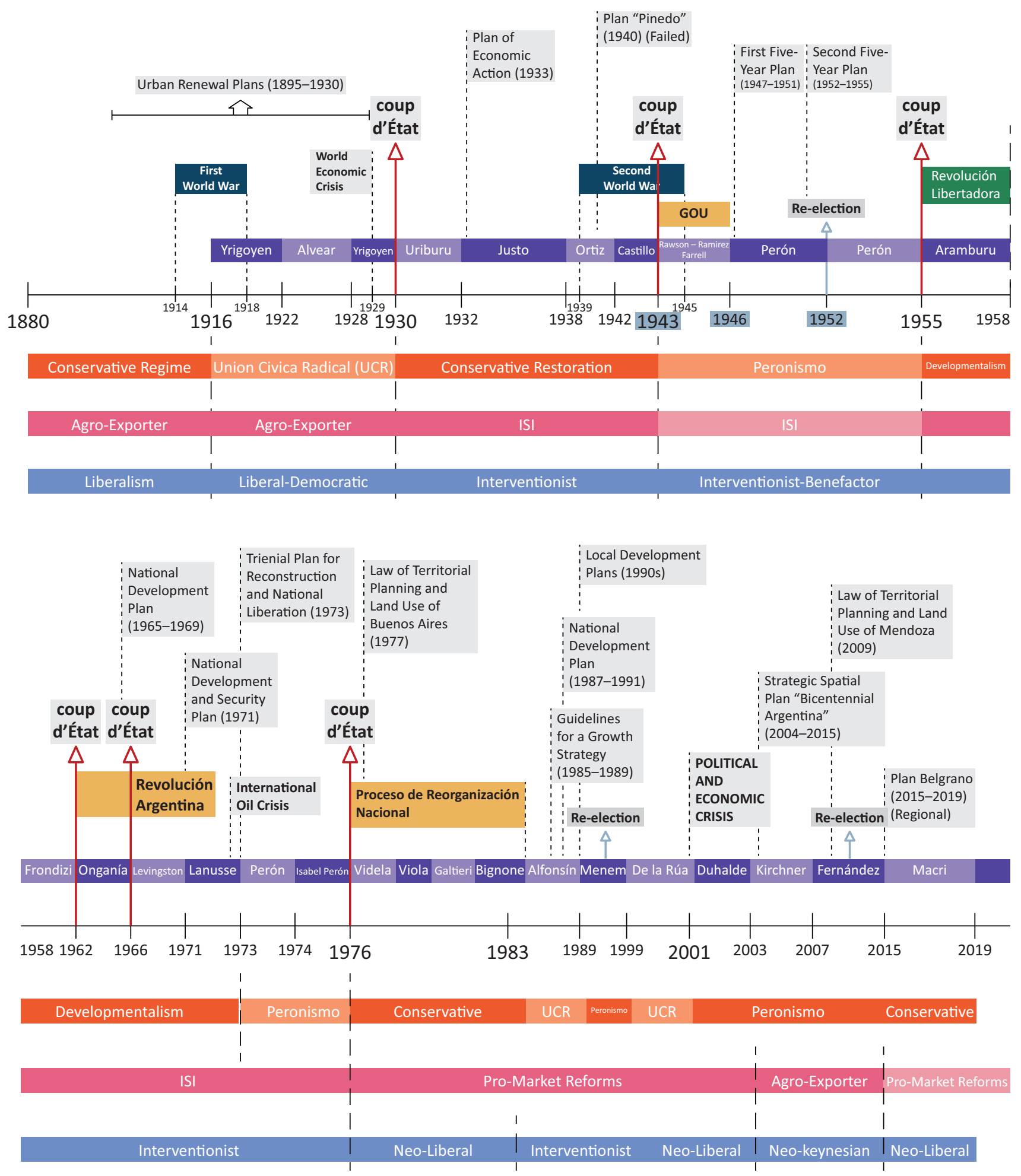

Figure 1. Continuities and changes affecting the evolution of governance in Argentina.

paradigm reduced the role of the national government in promoting a balanced and inclusive development. The main cities, such as Buenos Aires, Córdoba, Rosario and Mendoza, were presented as vigorous, agile and largely self-sufficient productive entities, capable of inno- vation and strong enough to boost economic growth nationally. Whilst competition grew among municipalities to attract foreign investment, the local scale became the main focus of planning (Catenazzi et al., 2019). International organisations (UNDP, OECD, World Bank, 
among others) sponsored 'Local Development Plans' in the belief that decentralised planning policies would encourage more efficient and innovative interventions. Thus, since the mid-1970s and especially during the 1990s, planning in neo-liberal Argentina was basically concentrated in ad hoc projects without a coherent national spatial strategy.

The 1990s were characterized by economic stability, with inflation kept in check. In the early years, privatization of state companies and public utilities made it possible to reduce debt. However, 1998-2002 were years of recession, with long-term effects on both politics and spatial organisation. In December 2001, President Fernando de la Rúa had to resign and was succeeded by five presidents in two weeks. The legacies of that recession are still visible: Infrastructure deteriorated, the shrinking economy relied more on informal jobs, undermining the potential for recovery. Inequality between classes and between regions grew.

The government of Néstor Kirchner (2003-2007) decided that the nation needed a long-term perspective again. Strategic guidelines for national development were articulated. Infrastructure investment, under the Ministry of Federal Planning, Public Investment and Services, was pivotal. The Under-secretariat for Spatial Planning of Public Investment was created to recover planning as a governance tool at the service of all levels of government. Its key achievement was the implementation of the Strategic Spatial Plan 'Bicentennial Argentina.' The plan devised a model of multi-level governance which was to guide the public investment process. Provinces participated through political representatives-mainly ministers of development, infrastructure and public works - in the elaboration of a national planning agenda.

\subsection{COFEPLAN and Its Preceding Steering Organisations}

The federal organisation of the country implies that spatial planning is a responsibility shared by the national, provincial and local political authorities (Erbiti, 2011). However, the national government lacks a legal framework to guide planning. With exceptions such as Buenos Aires and Mendoza, the provincial regulatory frameworks have great difficulty overseeing municipal land use planning. At the same time, provincial administrations create planning difficulties for municipalities.

Provinces over time delegated limited responsibilities to municipalities and where they did, sometimes resources did not follow responsibilities, in other cases, land use planning authority was not combined with local authority over other policy domains. This prevented municipalities from integrating land use planning with transportation systems and from developing long-term strategies for public works (Muzzini et al., 2017). Municipalities were granted greater planning autonomy through the 1994 constitutional reform, but they still lacked technical capacity and financial incen- tives to update land use regulations-another reason why provincial planning offices remain significant (Goytia et al., 2010). As a result, new planning initiatives involve coordination between different tiers of government. The COFEPLAN was created in December 2008 to address this coordination problem.

COFEPLAN is a national agency under the Ministry of Planning which brings together the City of Buenos Aires and the 23 provinces at least twice a year to discuss the development and harmonization of planning policies. Composed of three working committees, this Council "was given a mandate to issue guidelines that would address planning bottlenecks in the specific legal framework of each province" (Muzzini et al., 2017, p. 180). Those frameworks, in other words, were supposed to remain intact and remain guiding. COFEPLAN was not initially expected to produce policies, plans or projects, nor a national planning law. It was intended to promote knowledge dissemination, legislative work and consensus-building among decisionmakers. Nevertheless, it did participate in the drafting of several versions of the National Planning Law, versions presented to the National Congress in 2009, 2011, 2013 and 2018. However, some provinces put up strong resistance and the law has not yet been enacted (Muzzini et al., 2017).

Praised as innovative (Corti, 2008), COFEPLAN was not entirely a first. Different steering organisations promoting national policies for land management and territorial development predated the organisation. In order to understand the functioning of COFEPLAN, its possibilities and limits of steering, we need to understand the evolution of national steering organisations leading to COFEPLAN. Figure 2 summarizes the development.

The National Postwar Council (CNP) was created by the military regime after the coup d'état of 1943 with the aim of conducting "studies on the social and economic ordering of the country...its coordination, planning and implementation" (Official Bulletin of the Argentine Republic, 1944). This Council was part of a network of planning and economic management organisations-some already installed since the 1930s-promoting State interventionism and centralized decision-making (Gómez \& Tchordonkian, 2010). Domestic industry had expanded during the War and the government was worried about normalization of international trade. The CNP produced a Plan for Social and Economic Ordering which was supposed to help the country facing stiffer competition after the war. It created agencies to analyse the socio-economic conditions of each province. Public and private sector actors competed for influence over the definition of priorities for public investment (Belini, 2009).

Coordination of sectorial interests through a network of public agencies was the main form of national-level planning, while institutional capacity developed through absorption of academic experts, private sector specialists and already existing technical units. The CNP was 
remarkably ambitious. It intended to coordinate the activities of several ministries towards national development goals (Gómez \& Tchordonkian, 2010). Studies conducted by the CNP gave shape to the First Five-Year Plan, a development strategy combining economic and spatial planning (as in socialist countries).

In September 1948 an Inter-ministerial Coordinating Council was established in order to overcome the administrative problems encountered during plan implementation. This Council was responsible for "comprehensive planning, coordination and verification of the evolution of the plan within all state agencies" (Falivene \& Dalbosco, 2007, p. 13). Additionally, the Federal Coordinating Council was launched to manage problems arising between the national government and the provinces. Later, in 1950, the National Planning Direction was organized under the Ministry of Technical Affairs with the task of studying and proposing a "scientific organisation of government and administration" (Official Bulletin of the Argentine Republic, 1949). In 1951, the Inter-ministerial Coordinating Council became the National Planning Council (see Figure 2).

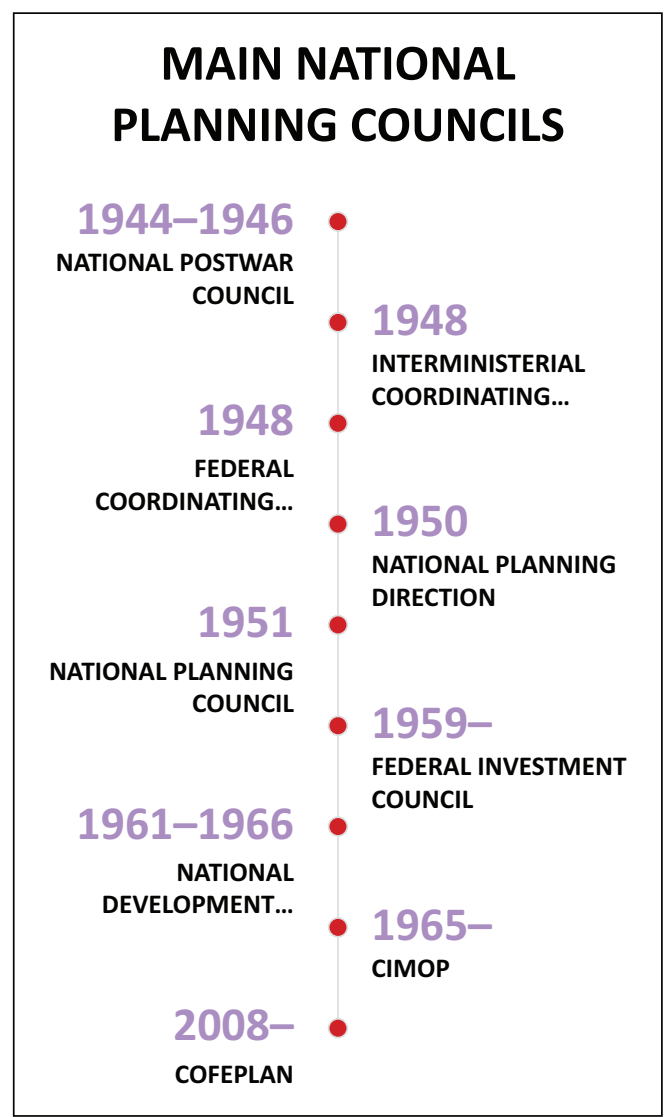

Figure 2. The main planning councils that preceded COFEPLAN.

The Federal Investment Council-created in 1959-is also an early reference for what COFEPLAN would later be, dating back to the so called 'golden era' of planning in Argentina (Canelo, 2012). The mission assigned to the Federal Investment Council was very similar to that of COFEPLAN: To promote the harmonious and comprehensive development of the country based on solidarity and decentralization. At the same time, the influence of Buenos Aires never really abated, and the collaboration between ministries, and between ministries and provinces, was never easy (Keeling, 1994; Loew, 1977). The Federal Investment Council was behind the establishment of CONADE, in 1960, which then led to the adoption of the 'National Development Plan' of 1965. That plan in turn was supported by a new organisation, the Inter-provincial Council of Ministers of Public Works. The organisation still exists and brings together top officials of Public Works and Services of the provinces. The Inter-provincial Council of Ministers of Public Works opened up intra-governmental processes of participation and became a precedent-setting organisation that has been instrumental in positioning COFEPLAN as a main steering organisation.

\subsection{COFEPLAN and Its Results}

Despite the difficulties inherent to a fragmented and fragile institutional framework, COFEPLAN achieved progress in several areas. It increased the political clout and technical capacities of local planning offices. This enabled them to develop a more integral territorial approach to administration. In addition, COFEPLAN created administrative mechanisms to promote inter-sectorial and interjurisdictional collaboration between government agencies. This often benefited the coordinated expansion of infrastructure networks. COFEPLAN further assumed responsibilities in the regulatory scaffolding of planning, even when law-making in planning is reserved for the provinces under the terms of article 121 of the National Constitution (Maldonado, 2010). Moreover, as shown in Table 1, the Council has contributed on several occasions to different Drafts of the Framework Law and, at present, is working on a draft Law of Territorial Planning and Habitat.

\section{Analysis}

Argentina has a unique history of governance. Economic recessions, currency collapse, military coups and ideological shifts were major shocks to society and to the governance system (Duit \& Galaz, 2008). In this situation, it is not evident that long-term perspectives and strategies can develop, be maintained, and adapted. Resources could evaporate after a crash, hierarchies reshuffled after a coup, and lower-level governments and regions abandoned.

Nevertheless, dependencies in the evolution of governance and planning can be distinguished. In terms of spatial planning the most dramatic system shock was the period 1975-2002, a generation where the national ideology seemed decidedly anti-planning (Müller, 2011). In that period, provinces had not given up on economic and spatial planning, and even de-centralizing policies 
Table 1. Main results achieved by COFEPLAN.

\begin{tabular}{|c|c|}
\hline Year & Results \\
\hline 2009 & $\begin{array}{l}\text { Survey of the situation of the provinces } \\
\text { Comparative analysis of planning and development laws in different countries } \\
\text { Draft Framework Law on Territorial Planning (first sketch) }\end{array}$ \\
\hline 2010 & $\begin{array}{l}\text { Training agreement with national universities } \\
\text { National and international forum on spatial planning and land use planning } \\
\text { Training of provincial technical teams } \\
\text { Diagnosis of progress in the development of geographic information systems and spatial data infrastructure in } \\
\text { each province } \\
\text { Diagnosis of the relationship between provincial planning teams and the provincial cadastres } \\
\text { Draft Framework Law on Territorial Planning } \\
\text { Reports on the state of affairs of provincial legislation regarding land use planning } \\
\text { National Meeting 'Territorial Planning as State Policy' }\end{array}$ \\
\hline 2011 & $\begin{array}{l}\text { 'Declaration of Iguazú' on the need to strengthen COFEPLAN, promote the draft law, support provincial } \\
\text { and local legislative initiatives, spur institutional strengthening and contribute to making territorial } \\
\text { problems visible } \\
\text { Discussion forum on the Draft Framework Law on Territorial Planning }\end{array}$ \\
\hline
\end{tabular}

2012 Foresight workshops 'The territories of the future'

Modification of the Draft Framework Law on Territorial Planning

2013 Formation of a federal planning network

Modification of the Draft Framework Law on Territorial Planning

Creation of a system of territorial indicators

2014 Creation of the Identification and Weighting System for Strategic Projects

Bases for the elaboration of provincial laws

Border Territorial Integration program

Planning and Territorial Ordering Guidelines document

Contribution to the Spatial Data Infrastructure of the Argentine Republic (IDERA)

Characterization of territories based on the law of environmental protection of native forests

Regional Commission of the Colorado River Basin

2015 Act of agreement on the Preliminary draft of the Framework Law on Territorial Planning

2016 Agreement for institutional strengthening between the Secretary of Strategic Planning, Land Management and Habitat, the Under-secretariat of Planning and Infrastructure and the Under-secretariat of Territorial Planning of Public Investment

Act of adhesion to the Program of Institutional Strengthening for Territorial Planning whereby the national government would provide financing for equipment and training

Creation of the Federal Urban Observatory

Seminars on urban issues and Disaster Risk Reduction

2018

Draft Framework Law on Territorial Planning

2019 Implementation of the Prosperous Cities Index (UN methodology)

Reconstruction Process in Comprehensive Risk Management (book)

Study of the expansion of the urban area

aiming to empower local governments, often ended up empowering provinces (Ardanaz et al., 2014). In addition, the instabilities at national level caused a slow accumulation of power at the provincial level. The national crises did not only make planning more difficult, but they also caused a recurring demand and hope for planning. When Argentina finally emerged out of the crisis of 1998-2002, that response, the call for planning, was not an isolated event, but depended on the institutional memory in governance, and in academia. That a 'golden age' of planning 
is recognized in the 1950s-1970s indicates the nostalgia for and identification with national level planning projects. The provinces had to be acknowledged in any revival of such project (Calvo \& Escolar, 2005). While the fragmentation of local power had to be addressed, if any national strategy wanted to have the territorywide effects envisioned. The Inter-provincial Council of Ministers of Public Works survived as the kernel of a coordination mechanism.

In the case of Argentine planning, an enabling factor, or a positive path dependency, is clearly the Peronist legacy. In Peronist ideology territorial integrity, integration, and development were primary aims. A strong state apparatus was considered the locus for national strategies towards those aims (Berrotarán, 2003). Several regimes identified as Peronists and a simple left-right ideological label cannot be applied to the movement and the discourse. Within the same regime, there could be signals and state actors which can be interpreted as far left and others as far right, while many actors would simply consider themselves 'Peronists.' The 'golden age' of planning was a period where economic and spatial planning (in socialist tradition) was integrated in national strategies. Different from socialist states, such as the USSR, Peronist Argentina did not develop the stability and the detailed hierarchical organisation which would allow for the local implementation of a national planning strategy.

The reality effects of previous national strategies were overall weak therefore, with few exceptions in peripheral regions, where the national planning agencies could engage in relatively unchecked development projects. When national planning re-emerged, and COFEPLAN emerged, acceptance of a national planning strategy therefore was strong. Yet, strong provinces and fragmented local institutions-legacies of the history of instability-could not be ignored (Benton, 2009). The legacies make it hard to coordinate between levels, between places, and between sectors and policy domains, while such coordination is all the more necessary because problems became more complex over time. The prevalence of informal institutions, settlements, and jobs-also responses to continued instability and state absence-aggravates this institutional weakness, makes it harder to recover economically and to steer from the centre.

Even in times of decentralization and in periods focusing on peripheral development, the general assumption in national politics was that what is good for Buenos Aires is good for Argentina. As the population of the capital also boomed, and as economic capital and elites concentrated in the capital, the city became harder and harder to ignore. It could not be treated as just a city. The constitutional reform of 1994 granted the city an autonomous regime. Hence its presence in COFEPLAN, together with the provinces. The pattern of interdependencies which developed is thus rather complex, with national agencies depending on provinces less willing to accept national strategies, on Buenos Aires, which sees itself as the country. Provinces are dependent on municipalities but also unable to push through comprehensive strategies because of institutional fragmentation and weakness at the local level (Tommasi, 2002). Growing municipalities might not have had the means to organize this growth, while places with plans did not see much growth, and whatever happened tended to be disconnected from those plans.

At the national level, the planning agencies competed with other actors, often with other ministries. Those ministries had their own projects, sometimes strategies, their own relations with provinces and local governments. The rhetoric of policy integration thus never fully resonated with reality, even when national planning strategies had broad support and were enacted. Elite competition, which included segments of political, economic, military and sometimes academic elites, transpired in the competition between ministries and their projects (Van Gunten, 2015). It undermined the reality effects of any overarching strategy for spatial development. One seeming constant was the emphasis on infrastructure works, often not under the auspices of a national planning authority, but at least associated with national administration. When COFEPLAN was formed, this looked then as a natural terrain, an initial core, for a national spatial policy. On the other hand, other national actors were not interested in handing control to COFEPLAN, and, without far-reaching policy coordination with local and regional governments, infrastructure could not function properly as a driver of economic development.

Social housing, also close to the COFEPLAN mandate, proved even more difficult (Catenazzi et al., 2019). Social housing is arguably even more important for inclusive economic development, but notoriously expensive and hard to coordinate. The meagre achievements of COFEPLAN on this terrain are not surprising, therefore. That the even harder task of coordinating housing, infrastructure and land use, where most added value for any national planning strategy ought to be found, could not be fulfilled, is not surprising either. The path creation that became possible after the prolonged shock of 1998-2002 could not create an entirely new path.

The effects of earlier strategies on governance are thus far from a history of 'implementation.' Goal dependencies slowly crystallized, modified by external shocks which diverted them from producing strong reality effects. The fragmented institutional landscape that now hinders a national planning strategy cannot be attributed merely to those external shocks. It should also be considered a result of older goal dependencies in the landscape of multi-level governance, a history of diverse responses to national steering attempts. An oscillation between belief in central planning ambitions, and, on the other hand, a cynical distrust of any planning initiative, further hampers the formation of reality effects in the direction intended by the national strategy (Müller \& Gómez, 2013). 


\section{Conclusions}

The creation of COFEPLAN signalled a renewed central steering ambition in Argentine planning. It was enabled by path dependencies which included the existence of a coordinating organisation linking to provincial public works ministries. There was the memory of a golden age of national planning, a lingering modernist-Peronist idea of territorial development and integration. The steering ambitions were hindered by other path dependencies, including weak and fragmented local governance, and provinces which emerged as more powerful from the history of ups and downs in Argentina (Ardanaz et al., 2014). That same fragmented landscape can be interpreted partly as a result of old goal dependencies. Infrastructure projects across the country, interpreted as a sign that the centre could steer, can be seen as a material dependency, yet not in the direction intended by the new strategy. Dependencies undermined both the central steering ambitions of the government and the innovative potential of the new planning schemes.

Ideologies of national planning, as discourses underpinning steering attempts, can lose and regain explanatory power in relation to an environment that adapts to new narratives. Society in Argentina responded to shocks, to a sometimes devastating oscillation between great expectations and dashed hopes. National planning is an unlikely survivor of such structural instability. National-level planning in Argentina re-emerged out of a set of (in)formal rules that have been re-assembled multiple times under different ideological influences and in relation to a shifting governance environment (Müller \& Gómez, 2013). A core of shared Peronism fits a core planning goal of addressing 'territorial imbalances,' which could be embraced under different regimes, and formed an argument for planning as such. While the difference between ideology and reality in Peronism created an eternal return of implementation problems for any national planning strategy. Elite competition, left-right cracks within the ideology, reduction of planning to infrastructure projects, the dominance of Buenos Aires, were all part of reality from the beginning, while flying in the face of an ideology of inclusive, integrative development under national auspices.

A more general lesson transpires here. Steering through managing the reality effects of strategy is dependent on both the legacies and the memories of previous steering attempts. This we knew from the history of the high modernist state, as studied by Scott (1998), but also by Luhmann (1997), who observed that steering is made easier first of all by a history of steering. We can add that, in a revival of steering, several features of that history are relevant in understanding the fate of future attempts. First there is the balance between continuity and discontinuity in governance, with discontinuity generally undermining enabling legacies for steering, but sometimes creating windows of opportunity, by creating a new appreciation of stability and of long-term futures (cf. Van Assche et al., 2021). Second, there is the relation between formal and informal institutions in the governance system, with a reliance on informality generally indicating fragmentation, weak governance, and low reality effects of strategy. Third, there is the internal cohesion of the steering ideology. When cohesion is weak the difference between rhetoric and reality will be significant, and this contributes to the divergence between intention and actual effects. Certainly, these internal cracks might be forgotten and old problematic decisions can be repeated. In terms of goal dependencies, this can be translated not as a typology of dependencies, but as a typology of contexts which will shape those dependencies.

\section{Acknowledgments}

We thank the editorial team at Politics and Governance and the three anonymous reviewers for helpful comments.

\section{Conflict of Interests}

The authors declare no conflict of interests.

\section{References}

Adler, P. S., Forbes, L. C., \& Willmott, H. (2007). Critical management studies. Academy of Management Annals, 1(1), 119-179.

Albrechts, L. (2004). Strategic (spatial) planning re examined. Environment and Planning B: Planning and Design, 31(5), 743-758.

Álvarez, G. P. (2016). Polos de desarrollo, acumulación originaria y expansión capitalista: Un estudio comparativo del estado argentino, brasileño y español [Development poles, original accumulation and capitalist expansion: A comparative study of the Argentine, Brazilian and Spanish state]. Theomai, 34, 88-103.

Alves Rolo, R. H. (2021). The persistent reinvention of state-led planning policies in Argentina: Exploring path dependencies and policy ruptures. Planning Perspectives, 36(1), 49-74.

Alvesson, M., \& Willmott, H. (2011). Critical management studies. Sage.

Ardanaz, M., Leiras, M., \& Tommasi, M. (2014). The politics of federalism in Argentina and its implications for governance and accountability. World Development, $53,26-45$.

Beckert, J. (2016). Imagined futures: Fictional expectations and capitalist dynamics. Harvard University Press.

Belini, C. (2009). La industria peronista, 1946-1955: Políticas públicas y cambio estructural [The Peronist industry, 1946-1955: Public policies and structural change]. EDHASA.

Benton, A. (2009). What makes strong federalism seem 
weak? Fiscal resources and presidential-provincial relations in Argentina. Publius: The Journal of Federalism, 39(4), 651-676.

Berrotarán, P. (2003). Del plan a la planificación: El estado durante la época Peronista [From plan to planning: The state during the Peronist era]. Imago Mundi.

Beunen, R., \& Lata, I. B. (2021). What makes long-term perspectives endure? Lessons from Dutch nature conservation. Futures, 126, Article 102679.

Beunen, R., Van Assche, K., \& Duineveld, M. (2015). Evolutionary Governance Theory: Theory and applications. Springer.

Birchall, S. J. (2020). Coastal climate adaptation planning and evolutionary governance: Insights from Homer, Alaska. Marine Policy, 112, Article 103410.

Boschma, R. A., \& Martin, R. (2007). Constructing an evolutionary economic geography. Journal of Economic Geography, 7, 537-548.

Byrne, D. S. (1998). Complexity theory and the social sciences: An introduction. Psychology Press.

Calvo, E., \& Escolar, M. (2005). La nueva política de partidos en la Argentina: Crisis política, realineamientos partidarios y reforma electoral [The new party policy in Argentina: Political crisis, party realignments and electoral reform]. Prometeo.

Canelo, P. (2012). Los efectos del poder tripartito: La balcanización del gabinete nacional durante la última dictadura militar argentina [The effects of tripartite power: The Balkanization of the national cabinet during the last Argentine military dictatorship]. Prohistoria: Historia, Políticas de la Historia, 17, 129-150.

Catenazzi, A., Reese, E., \& Mango, A. (2019). 20 years of Habitat II: The pending subjects. In M. Cohen, M. Carrizosa, \& M. Gutman (Eds.), Urban policy in Latin America: Towards the Sustainable Development Goals? (pp. 203-260). Routledge.

Cerrutti, M., \& Bertoncello, R. (2006). Urbanization and internal migration patterns in Latin America. In $\mathrm{M}$. Tienda, S. Findley, S. Tollman, \& E. Preston-Whyte (Eds.), African migration and urbanization in comparative perspective (pp. 141-156). Wits University Press.

Ciccolella, P. (2006). Metrópolis latinoamericanas: ¿Territorios subregulados, espacios del capital? [Latin American metropolises: Underregulated territories, spaces of capital?]. In A. Aguilar (Ed.), Las grandes aglomeraciones y su periferia regional: Experiencias en Latinoamérica y España [Large agglomerations and their regional periphery: Experiences in Latin America and Spain]. Porrúa Editor.

Corti, M. (2008). La ausencia de una legislación territorial en la Argentina [The absence of territorial legislation in Argentina]. Cafe de las Ciudades. https:// cafedelasciudades.com.ar/planes_72_2.htm

Crot, L. (2006). "Scenographic" and "cosmetic" planning: Globalization and territorial restructuring in Buenos Aires. Journal of Urban Affairs, 28(3), 227-251.
David, P. A. (1994). Why are institutions the 'carriers of history'? Path dependence and the evolution of conventions, organizations and institutions. Structural Change and Economic Dynamics, 5(2), 205-220.

Djanibekov, U., Van Assche, K., Boezeman, D., Villamor, G., \& Djanibekov, N. (2018). A coevolutionary perspective on the adoption of sustainable land use practices: The case of afforestation on degraded croplands in Uzbekistan. Journal of Rural Studies, 59, 1-9.

Dopfer, K. (1991). Toward a theory of economic institutions: Synergy and path dependency. Journal of Economic Issues, 25(2), 535-550.

Duit, A., \& Galaz, V. (2008). Governance and complexity: Emerging issues for governance theory. Governance, 21(3), 311-335.

Elena, E. (2005). What the people want: State planning and political participation in Peronist Argentina, 1946-1955. Journal of Latin American Studies, 37(1), 81-108.

Erbiti, C. (2011). Políticas de ordenamiento ambiental del territorio en la Argentina contemporánea [Policies of environmental planning of the territory in contemporary Argentina]. Revista Geográfica de América Central, 47(2), 1-17.

Fairhurst, G. T., \& Putnam, L. (2004). Organizations as discursive constructions. Communication Theory, 14(1), 5-26.

Falivene, G., \& Dalbosco, H. (2007). El impacto del primer Plan Quinquenal (1947-1951) en la configuración del Estado [The impact of the first Five-Year Plan (1947-1951) on the configuration of the State]. Asociación Argentina de Estudios en Administración Pública.

Flyvbjerg, B. (1998). Rationality and power: Democracy in practice. University of Chicago Press.

Foucault, M., \& Miskowiec, J. (1986). Of other spaces. Diacritics, 16(1), 22-27.

Fuenfschilling, L., \& Truffer, B. (2016). The interplay of institutions, actors and technologies in sociotechnical systems: An analysis of transformations in the Australian urban water sector. Technological Forecasting and Social Change, 103, 298-312.

George, B. (2020). Successful strategic plan implementation in public organizations: Connecting people, process, and plan (3Ps). Public Administration Review. https://doi.org/10.1111/puar.13187

Gómez, T., \& Lesta, M. (2008). La planificación en Argentina en la primera mitad del Siglo XX [Planning in Argentina in the first half of the twentieth century]. Paper presented at XXI Jornadas de Historia Económica, Buenos Aires, Argentina.

Gómez, T., \& Tchordonkian, S. (2010). El Consejo Nacional de Posguerra (1944-46), diagnósticos y tensiones en el diseño de políticas públicas [The National Postwar Council (1944-46), diagnoses and tensions in the design of public policies]. Paper presented at Segundo Congreso Latinoamericano de Historia Económica, Mexico City, Mexico. 
Goytia, C., Mendoza, C., \& Pasquini, R. (2010). Land regulation in the urban agglomerations of Argentina and its relationship with households' residential tenure condition. (Working Paper No. 10CC1). Lincoln Institute of Land Policy.

Greener, I. (2005). The potential of path dependence in political studies. Politics, 25(1), 62-72.

Greif, A. (2006). Institutions and the path to the modern economy: Lessons from medieval trade. Cambridge University Press.

Grey, C., \& Willmott, H. (Eds.). (2005). Critical management studies: A reader. Oxford University Press.

Hajer, M. A. (1993). Discourse coalitions and the institutionalization of practice: The case of acid rain in Great Britain. In F. Fischer \& J. Forester (Eds.), The argumentative turn in policy analysis and planning (pp. 43-76). Duke University Press.

Hoffman, J. (2013). Theorizing power in transition studies: The role of creativity and novel practices in structural change. Policy Sciences, 46(3), 257-275.

Jarzabkowski, P. (2005). Strategy as practice: An activity based approach. Sage.

Jarzabkowski, P., Balogun, J., \& Seidl, D. (2007). Strategizing: The challenges of a practice perspective. Human Relations, 60(1), 5-27.

Johnson, G., Langley, A., Melin, L., \& Whittington, R. (2007). Strategy as practice. Cambridge University Press.

Keeling, D. J. (1994). Regional development and transport policies in Argentina: An appraisal. The Journal of Developing Areas, 28(4), 487-502.

Latour, B. (2005). Reassembling the social: An introduction to actor-network-theory. Oxford University Press.

Liebowitz, S., \& Margolis, S. E. (1995). Policy and path dependence: From QWERTY to Windows 95. Regulation, 18, Article 33.

Loew, E. S. (1977). Argentina: Realities of planning. Built Environment Quarterly, 3(1), 20-23.

Luhmann, N. (1990). Political theory in the welfare state. De Gruyter.

Luhmann, N. (1995). Social systems. Stanford University Press.

Luhmann, N. (1997). Limits of steering. Theory, Culture \& Society, 14(1), 41-57.

Luhmann, N. (2008). The autopoiesis of social systems. Journal of Sociocybernetics, 6(2), 84-95.

Maldonado, M. L. (2010). Reflexión sobre la reforma urbana [Reflection on the urban reform] [Unpublished specialization dissertation]. Universidad Nacional de Rosario.

Marengo, C. (2008). Urban sprawl and spatial planning: Facing the challenges of growing social inequity. Case study: Córdoba, Argentina [Doctoral thesis, Delft University]. Universidad Nacional de Córdoba. https:// rdu.unc.edu.ar/handle/11086/1841

Martin, R., \& Sunley, P. (2006). Path dependence and regional economic evolution. Journal of Economic
Geography, 6(4), 395-437.

Mintzberg, H. (1978). Patterns in strategy formation. Management Science, 24(9), 934-948.

Mintzberg, H. (1987). Crafting strategy. Harvard Business School Press.

Müller, A. (2011). La (no) planificación en la Argentina de los '90 y los 2000: Apuntes para una historia y posibles lecciones para el futuro [The (non) planning in the '90s and 2000s Argentina: Notes for a history and possible lessons for the future]. Realidad Económica, 260, 24-53.

Müller, A., \& Gómez, T. (2013). La planificación en Argentina en perspectiva (1930-2012) [Planning in Argentina in perspective (1930-2012)]. CESPA.

Muzzini, E., Eraso Puig, B., Anapolsky, S., Lonnberg, T., \& Mora, V. (2017). Leveraging the potential of Argentine cities: A framework for policy action. World Bank.

North, D. C. (1990). Institutions, institutional change and economic performance. Cambridge University Press.

North, D. C. (2005). Understanding the process of economic change. Princeton University Press.

Official Bulletin of the Argentine Republic. (1944). Decree No. 23.847.

Official Bulletin of the Argentine Republic. (1949). Organic Law on Ministries No. 13.532.

Official Bulletin of the Argentine Republic. (1951). Decree No. 5291.

Pierson, P. (2000). Increasing returns, path dependence, and the study of politics. American Political Science Review, 94(2), 251-267.

Richardson, T. (1996). Foucauldian discourse: Power and truth in urban and regional policy making. European Planning Studies, 4(3), 279-292.

Rigotti, A. (2014). Las invenciones del urbanismo en Argentina (1900-1960): Inestabilidad de sus representaciones científicas y dificultades para su profesionalización [The inventions of urbanism in Argentina (1900-1960): Instability of its scientific representations and difficulties for its professionalization] [Doctoral thesis, Universidad Nacional de Rosario]. Universidad Nacional de Rosario. https://rephip.unr.edu.ar

Schlüter, A., Van Assche, K., Hornidge, A. K., \& Văidianu, N. (2020). Land-sea interactions and coastal development: An evolutionary governance perspective. Marine Policy, 112, Article 103801.

Schreyögg, G., \& Sydow, J. (Eds.). (2009). The hidden dynamics of path dependence: Institutions and organizations. Springer.

Scott, J. C. (1998). Seeing like a state: How certain schemes to improve the human condition have failed. Yale University Press.

Seabright, P. (2010). The company of strangers: A natural history of economic life-revised edition. Princeton University Press.

Seabrooke, L., \& Wigan, D. (2016). Powering ideas through expertise: Professionals in global tax battles. Journal of European Public Policy, 23(3), 357-374. 
Seidl, D. (2007). General strategy concepts and the ecology of strategy discourses: A systemic-discursive perspective. Organization Studies, 28(2), 197-218.

Settimi, S. M., \& Audino, P. (2008). La influencia de Keynes en la evolución de las ideas económicas de Raúl Prebisch y su aplicación en Argentina, 1930-1943 [The influence of Keynes in the evolution of the economic ideas of Raúl Prebisch and its application in Argentina, 1930-1943]. Análisis Económico, 23(54), 225-237.

Streeck, W., \& Thelen, K. A. (Eds.). (2005). Beyond continuity: Institutional change in advanced political economies. Oxford University Press.

Teubner, G. (1993). Law as an autopoietic system. Blackwell Publishers.

Teubner, G. (2011). Networks as connected contracts. Bloomsbury Publishing.

Thrift, N. (1999). The place of complexity. Theory, Culture \& Society, 16(3), 31-69.

Tommasi, M. (2002). Federalism in Argentina and the reforms of the 1990s. Universidad de San Andrés.

Torfing, J. (2009). Rethinking path dependence in public policy research. Critical Policy Studies, 3(1), 70-83.

Under-secretariat of Territorial Planning of Public Investment. (2015). Lineamientos para la planificación territorial de la República Argentina [Guidelines for the territorial planning of the Argentine Republic]. Ministry of Interior.

Van Assche, K., Beunen, R., \& Duineveld, M. (2014). Evolutionary Governance Theory: An introduction. Springer.

Van Assche, K., Beunen, R., Gruezmacher, M., \& Duineveld, M. (2020). Rethinking strategy in environmental governance. Journal of Environmental Policy \& Planning, 22(5), 695-708.

Van Assche, K., Verschraegen, G., \& Gruezmacher, M. (2021). Strategy for collectives and common goods: Coordinating strategy, long-term perspectives and policy domains in governance. Futures, 128, Article 102716.

Van Gunten, T. S. (2015). Cohesion, consensus, and conflict: Technocratic elites and financial crisis in Mexico and Argentina. International Journal of Comparative Sociology, 56(5), 366-390.

Whittington, R. (1996). Strategy as practice. Long Range Planning, 29(5), 731-735.

Wittmayer, J. M., Backhaus, J., Avelino, F., Pel, B., Strasser, T., Kunze, I., \& Zuijderwijk, L. (2019). Narratives of change: How social innovation initiatives construct societal transformation. Futures, 112, Article 102433.

\section{About the Authors}
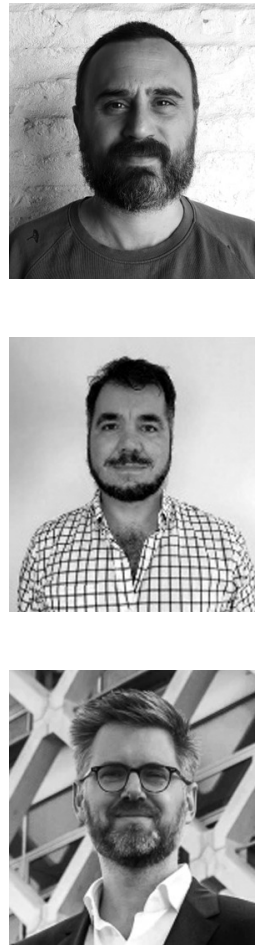

Rodrigo Alves Rolo is a Human Geographer. He holds an MA in rural development from the University of Buenos Aires and is currently a PhD Candidate at the Cultural Geography chair group (Wageningen University). His PhD project focuses on the path, inter and goal-dependencies shaping the formation of planning policies in Argentina at the beginning of the 21st century. He is also interested in the political dynamics of planning policy formations, democratic governance and the limits of collaborative decision-making.

Kristof Van Assche is Full Professor in planning, governance and development at the University of Alberta and also affiliated with Bonn University, Center for Development Research as Senior Fellow and with Memorial University, Newfoundland, Harris Centre for Regional Policy, as Research Fellow. He is interested in evolution and innovation in governance, with focus areas in spatial planning and design, development and environmental policy. Together with colleagues he has developed Evolutionary Governance Theory.

Martijn Duineveld is Associate Professor at the Cultural Geography Group (Wageningen University). His research programme is named Urban Governance and the Politics of Planning and Design. He is Co-Founder and active Contributor to the emerging body of literature on Evolutionary Governance Theory. Martijn has been involved in international research and consultancy projects in Argentina, Uganda, Georgia and Russia. His research focuses on democratic innovation in Urban Governance, conflicts and power in urban governance, and materiality and object formation in urban governance. 